\title{
The Role of Holocene Relative Sea-Level Change in Preserving Records of Subduction Zone Earthquakes
}

\author{
Tina Dura ${ }^{1,2}$ - Simon E. Engelhart ${ }^{3} \cdot$ Matteo Vacchi $^{4}$ - Benjamin P. Horton ${ }^{1,2,5}$. \\ Robert E. Kopp ${ }^{2,6} \cdot$ W. Richard Peltier ${ }^{7} \cdot$ Sarah Bradley $^{8}$
}

Published online: 7 July 2016

(C) Springer International Publishing AG 2016

\begin{abstract}
Eustasy and glacio- and hydro-isostatic adjustment are the main drivers of regional variability of Holocene relative sea-level (RSL) records. These regional variations in Holocene RSL influence the preservation of coastal wetland stratigraphic records of prehistoric earthquakes along subduction zone coasts. The length and completeness of prehistoric earthquake records is intrinsically linked to the accommodation space provided by gradually rising $(<3 \mathrm{~mm} / \mathrm{year})$ Holocene RSL. In near-field regions that were located beneath northern hemisphere ice sheets (e.g., western Vancouver Island), RSL fall from a mid-Holocene highstand has limited prehistoric earthquake records to the last $1 \mathrm{ka}$. In intermediate field regions (e.g., southern Washington and central Oregon), gradual RSL rise over the last $\sim 7 \mathrm{ka}$ has preserved widespread records of prehistoric earthquakes. In far-field regions (e.g., Sumatra, Chile, and Japan), fragmentary stratigraphic
\end{abstract}

This article is part of the Topical Collection on Sea Level Projections

Electronic supplementary material The online version of this article (doi:10.1007/s40641-016-0041-y) contains supplementary material, which is available to authorized users.

Tina Dura

dura@marine.rutgers.edu

1 Sea Level Research, Department of Marine and Coastal Science, Rutgers University, 71 Dudley Road, New Brunswick, NJ 08901, USA

2 Institute of Earth, Ocean, and Atmospheric Sciences, Rutgers University, New Brunswick, NJ, USA

3 Department of Geosciences, University of Rhode Island, Kingston, RI, USA evidence of prehistoric earthquakes has been preserved only during periods of gradual RSL rise prior to a mid-Holocene highstand, or during the last 1-3 ka, when RSL was within $2 \mathrm{~m}$ of modern sea level, and thus within the tidal frame.

Keywords Relative sea level - Glacio-isostatic adjustment . Prehistoric earthquakes $\cdot$ Accommodation space $\cdot$ Coastal wetland stratigraphy $\cdot$ Subduction zone

\section{Introduction}

Holocene relative sea-level (RSL) change is the net effect of eustatic factors (land ice mass change and ocean thermal expansion), regional glacio- and hydro-isostatic adjustment (GIA), ocean dynamics, tectonic uplift or subsidence, and other

4 Aix-Marseille Université, CEREGE CNRS-IRD UMR 34, Europole de l'Arbois BP, 80 Aix-en-Provence, France

5 Earth Observatory of Singapore and Asian School of the Environment, Nanyang Technological University, Singapore, Singapore

6 Department of Earth and Planetary Sciences and Rutgers Energy Institute, Rutgers University, New Brunswick, NJ, USA

7 Department of Physics, University of Toronto, M5S 1A7, Toronto, ON, Canada

8 Institute for Marine and Atmospheric Research Utrecht (IMAU), Utrecht University, Utrecht 3685, CC, the Netherlands 
local factors that produce complex patterns of RSL rise or fall over space and time [1-3]. These complex regional patterns of RSL change have influenced the deposition and preservation of sediment representing coastal wetland environments (e.g., tidal marshes and mangroves) that preserve stratigraphic records of Holocene RSL change [4-6]. The formation and preservation of coastal wetland stratigraphic sequences are strongly dependent on the accommodation space created by RSL change [7-9]. The most spatially and temporally complete coastal wetland stratigraphic archives are found along coastlines with gradually rising RSL during the Holocene [10]. In contrast, coastlines that have experienced an RSL fall [11] from a midHolocene highstand have fragmented and spatially limited coastal wetland stratigraphic records.

Holocene coastal wetland stratigraphy can preserve evidence of RSL change related to prehistoric earthquakes and tsunamis $[8,12-15]$. The societal and scientific value of prehistoric records of the largest, most infrequent subduction zone earthquakes and their tsunamis was underscored by the devastating impacts of the 2004 Indian Ocean and 2011 Tohoku events [16, 17]. If seismic and tsunami hazard assessments in these regions had fully considered coastal geologic evidence for past subduction zone earthquakes and tsunamis, losses might have been substantially reduced $[17,18]$. One of the most widely applied methods of reconstructing subduction zone earthquake histories on millennial timescales employs coastal wetland stratigraphic sequences to identify sudden changes in RSL during coseismic vertical deformation of the coast [12, 13, 19-21]. However, the time spans and completeness of prehistoric earthquake records varies widely among subduction zone coastlines.

In this review, we discuss the factors that drive patterns in Holocene regional RSL change along subduction zone coasts and how these patterns influence the formation of coastal wetland stratigraphic sequences likely to preserve evidence of past subduction zone earthquakes. We contrast the relatively complete Holocene stratigraphic archives of prehistoric earthquakes along the Cascadia subduction zone, where RSL has been gradually rising during the Holocene, with incomplete and fragmentary records from the subduction zone coasts of Sumatra, Chile, and Japan, where late Holocene (last $4 \mathrm{ka}$ ) sea-level fall has limited the preservation of prehistoric earthquake evidence. Considering stratigraphic records of coseismic vertical deformation in the context of Holocene RSL change reveals the most likely time periods and locations for the preservation of millennial-scale records of past earthquakes along various subduction zone coasts.

\section{Spatial Variability of Holocene Relative Sea-Level Change}

The largest contributor to Holocene RSL change was the melting of the northern hemisphere ice sheets (Fig. 1) [22], which both increased ocean volume and triggered isostatic responses of the solid earth [23, 24]. At the beginning of the Holocene $(\sim 12 \mathrm{ka})$, eustatic sea level was $\sim 60 \mathrm{~m}$ lower than in the present, due largely to the remaining Scandinavian and Laurentide ice sheets as well as a greater-than-present Antarctic Ice Sheet volume [25]. Rates of eustatic RSL rise slowed by $\sim 7 \mathrm{ka}$ following the terminal melting of the Laurentide Ice Sheet [26]. Between $\sim 7$ and 2 ka, only a fewmeter sea-level equivalent of ice-sheet mass loss occurred [25], mostly from the Antarctic Ice Sheet [27].

The spatial expression of RSL change during the Holocene varies among regions once covered by the northern hemisphere ice sheets (Fig. 1a; near-field), located at the periphery of these ice sheets (Fig. 1b; intermediate-field), and regions distant from these major glaciation centers (Fig. 1c-e; farfield) $[1,11,28]$.

Near-field regions are strongly influenced by local ice (un)loading, which produces vastly contrasting patterns in RSL change during the Holocene. Near the center of former northern hemisphere ice sheets (e.g., Hudson Bay), the rate of glacio-isostatic uplift exceeded the rate of eustatic sea-level rise during the Holocene [29]. But at the margins of the ice sheet (e.g., western Vancouver Island Canada), the rate of eustatic sea-level rise outpaced glacio-isostatic uplift until $\sim 7 \mathrm{ka}$, after which glacio-isostatic uplift became the dominant control on RSL, resulting in a mid-Holocene highstand [30].

RSL change in intermediate-field regions is influenced by the formation and collapse of the proglacial forebulge [31]. Ice loading during the last glacial maximum ( 26 ka; LGM) caused the migration of mantle material away from ice load centers, resulting in uplift of a forebulge at the periphery of ice sheets $[31,32]$. Progressive melting of the ice led to the collapse of this forebulge (glacioisostatic subsidence) as mantle material returned to the former load centers [33]. In intermediate-field regions (e.g., US Atlantic and Pacific coasts), isostatic and eustatic effects worked in tandem to produce rapid RSL rise up to $\sim 7 \mathrm{ka}$ BP [34]. After $7 \mathrm{ka}$, the eustatic input diminished and continuing glacio-isostatic subsidence became the predominant control on RSL rise [3, 28].

In far-field regions distant from northern hemisphere ice sheets (e.g., Atlantic and Pacific coasts of South America), eustatic, hydro-isostatic, and glacio-isostatic processes are dominant $[35,36]$. In these regions, the RSL pattern is characterized by a rise to a mid-Holocene sea-level high- or stillstand between $\sim 7$ and $5 \mathrm{ka}[37,38]$. The fall in RSL to present was produced when the rates of eustatic sea-level rise was exceeded by the combined effects of hydro-isostatic loading of the continental shelf (continental levering) and water migrating away from far-field equatorial ocean basins in order to fill space vacated by collapsing forebulges (equatorial ocean siphoning) $[1,2]$. 


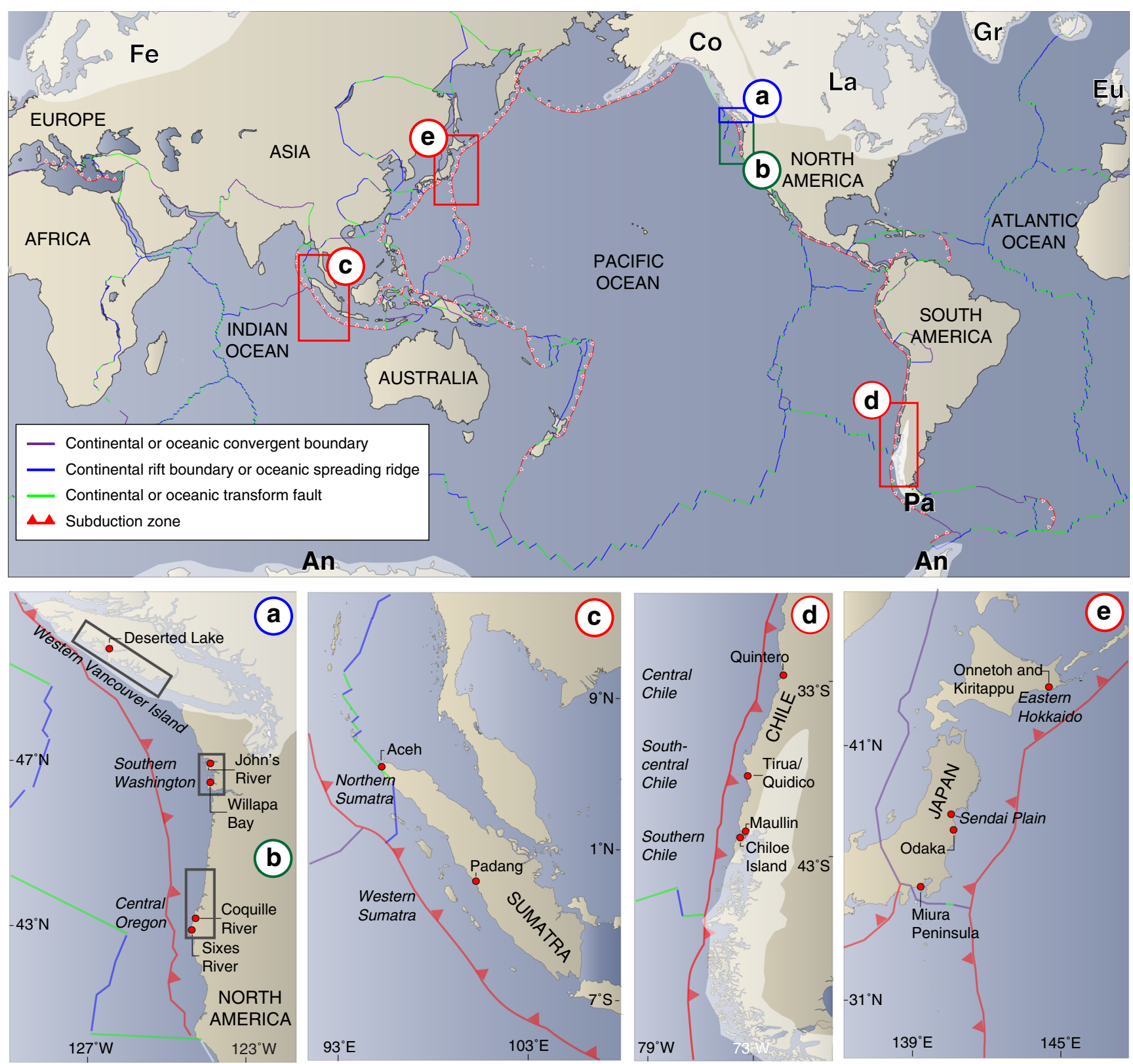

Fig. 1 Subduction zones referenced in this paper and their proximity to the major ice sheets of the Last Glacial Maximum $26 \mathrm{ka}$. A blue rectangle denotes the near field (a) portion of the Cascadia subduction zone, while a green rectangle denotes the intermediate field (b) portion. Subduction zones in the far-field regions of Sumatra (c), Chile (d), and Japan (e) are outlined in red. The approximate spatial extent of the major ice sheets at $\sim 21.5 \mathrm{ka}$ (lighter color) is redrawn after Kleman and Hättestrand [93], Anderson et al. [94], Dyke [95], Clague and James

\section{The Preservation of Stratigraphic Evidence of Earthquakes During Long-Term RSL Change}

Prior knowledge of the Holocene RSL history of a subduction zone is the first step in deciding which sites to target to reconstruct earthquake histories from coastal wetland stratigraphy. Increasing tidal inundation during
[96], and Moreno et al. [97]. Eu is Eurasian, $L a$ is Laurentide, Co is Cordilleran, $\mathrm{Pa}$ is Patagonian, and $\mathrm{Ar}$ is Antarctic. In the detailed view of the Cascadia subduction zone, the near-field (western Vancouver Island) and intermediate-field (southern Washington and central Oregon) RSL regions are outlined by rectangles. All subduction zone regions (in italics) and paleoearthquake study site locations (shown by red circles) referenced in the text and plotted in Figs. 4, 5, 7, and 8 are labeled on the detailed view of each subduction zone gradual $(<3 \mathrm{~mm} / \mathrm{year}) \mathrm{RSL}$ rise leads to increased sediment deposition and the growth and aggradation of wetland vegetation [39]. However, if RSL rises too fast $(>10 \mathrm{~mm} /$ year), organic matter contributions from coastal vegetation are reduced, accelerating erosion and replacing coastal wetlands with subtidal environments [9, 40, 41]. RSL fall starves coasts of sediment and limits 
coastal wetland formation to protected estuaries, barrier lagoons, and deltas where sediment supply is relatively high [42].

The accommodation space created by gradual ( $<3 \mathrm{~mm}$ /year) RSL rise promotes the formation of thick (Fig. 2a) sequences of coastal wetland stratigraphy [9, 41]. The most complete stratigraphic records with coseismic subsidence contacts are formed when gradual RSL rise enables coastal wetland soil $\mathrm{O}$ horizons submerged by abrupt coseismic subsidence to be quickly capped by sediment, protecting the contacts from soil development, bioturbation, and erosion (Fig. 3a) [13, $20,43-45]$. As the coast gradually uplifts during the interseismic period, gradual RSL rise continues to provide the accommodation space for sediment to aggrade and, eventually, for vegetation to form on the new wetland surface [46]. Coseismic uplift is preserved in the opposite manner (e.g., tidal flat mud overlain by a soil). As long as the uplifted surface remains in the intertidal zone, or in wet, boggy supratidal conditions with a high ground water table, gradual long-term RSL rise will provide the accommodation space for sediment and organic matter to aggrade without a significant interruption in sedimentation [47, 48]. Gradual long-term RSL rise creates stacks of well-preserved wetland soil O horizons buried by tidal flat mud (subsidence) or tidal muds overlain by wetland soil $\mathrm{O}$ horizons (uplift) that can be dated by radiocarbon to reconstruct the earthquake history at subduction zone sites [44, 49-52].
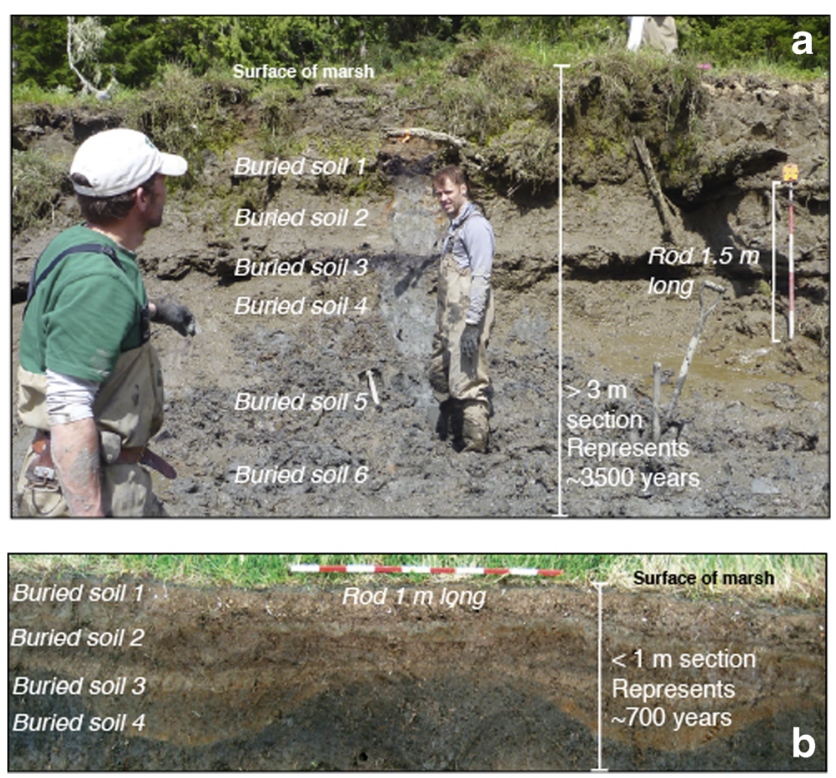

Fig. 2 Annotated photos of representative stratigraphic sections from the coasts of southern Washington (mid- to late-Holocene RSL rise) (a) and south-central Chile (late-Holocene RSL fall) (b). Buried soil O horizons represent prehistoric subduction zone earthquakes
At coastlines that experience long-term RSL fall, similar coseismic subsidence or uplift results in minimal burial of wetland soil $\mathrm{O}$ horizons and tidal flat mud because of limited accommodation space and low sedimentation rates [52-56]. Coastal wetland stratigraphic sequences that form under RSL fall are thin (Fig. 2b) and discontinuous with many unconformities. As the coast emerges out of the tidal frame during RSL fall, coastal wetlands are progressively stranded [42] and the upper sediment of emerged wetland stratigraphy is eventually bioturbated, oxidized, and incorporated into upland soils (Fig. 3b). Emergence also leads to sediment erosion that further obscures stratigraphic contacts $[8,53,56]$. Evidence of prehistoric earthquakes in such emerged wetland sequences is typically difficult to correlate among cores or sites [53].

\section{Regional RSL and Earthquake History}

In order to demonstrate the influence of differing rates of Holocene RSL change on the length and completeness of prehistoric earthquake records, we highlight RSL changes and earthquake histories at near-, intermediate-, and farfield regions at four subduction zones. Our near-field (western Vancouver Island) and intermediate-field (southern Washington, and central Oregon) regions are located along the Cascadia subduction zone. Cascadia's RSL history has been reconstructed using sea-level index points that record the position of RSL over time [57]. Each index point contains information about its (a) geographic location; (b) calibrated radiocarbon age and error $(2 \sigma)$; and (c) elevation of former sea level and its vertical error $(2 \sigma)$ [58]. Sea level index points for Cascadia are listed in a comprehensive RSL database for the Pacific coast of central North America [59].

To estimate rates of RSL change for the Cascadia subduction zone, we use a spatio-temporal empirical hierarchical statistical model, as in Kopp et al. [60]. The spatiotemporal model fits all index points simultaneously, not on a site-by-site basis. Details of the model are described in Online Resource 1.

Examples of subduction zones in far-field regions include the Sunda (northern and western Sumatra), Chile (central and southern Chile), and Japan (Sendai Plain, Tokyo metropolitan area, and eastern Hokkaido) subduction zones. Due to the absence of RSL databases in our far-field regions, we relied on glacio-isostatic adjustment model predictions to characterize RSL change over the Holocene [33, 61]. For each far-field region, we generated sea-level predictions using two GIA models - the ICE-6G_C (VM6) model [33] and the ICE model [61]. 
b Intermediate region of gradual $(<3 \mathrm{~mm} / \mathrm{yr}) \mathrm{RSL}$ rise
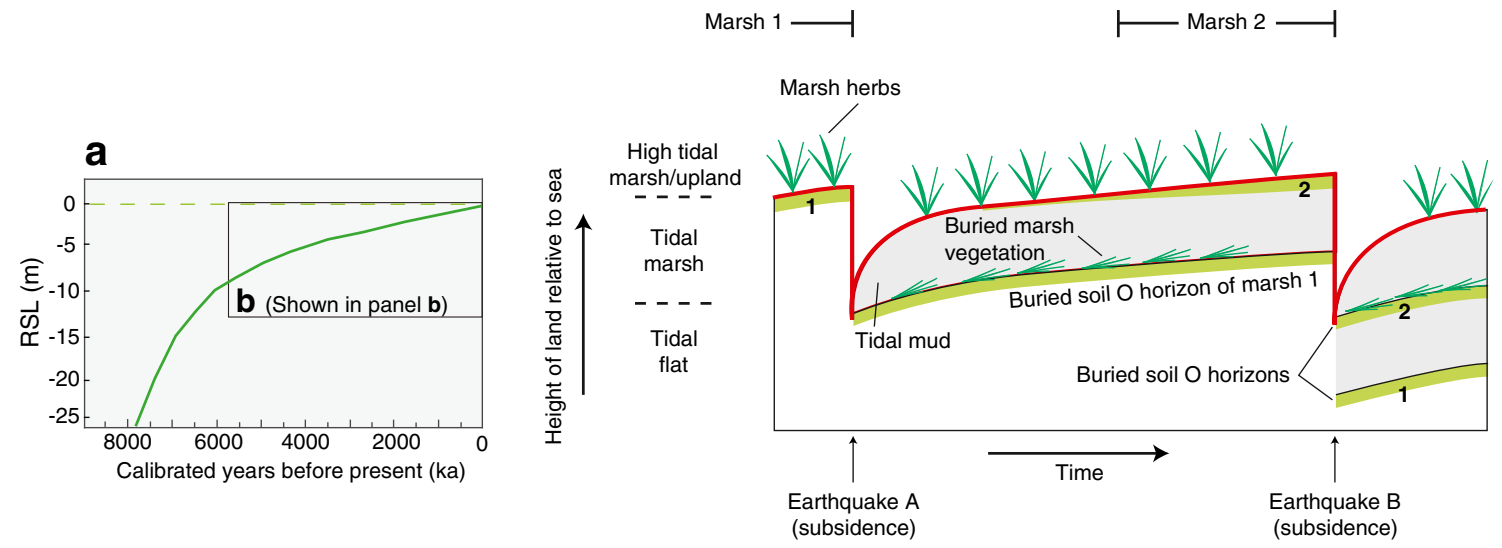

d Far-field region of gradual RSL fall
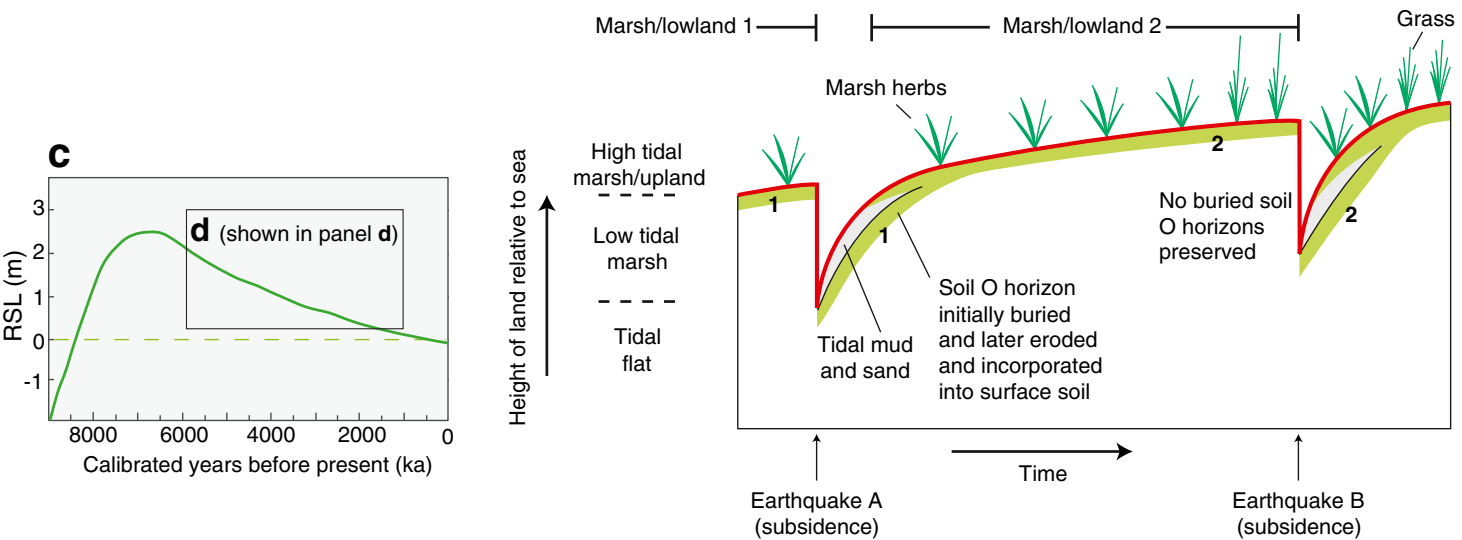

Fig. 3 Simplified models of land-level change in estuary tidal wetlands during two earthquake cycles above a subduction zone experiencing gradual RSL rise $(\mathbf{a}, \mathbf{b})$ and a subduction zone experiencing RSL fall (c, d). Heavy red line shows inferred land-level change relative to sea level. In $\mathbf{b}$, tidal marsh soil $\mathrm{O}$ horizons $(1,2)$ are quickly buried by many decimeters of tidal mud following coseismic subsidence due to modest postseismic recovery and slowly rising sea level. This process creates

stacks of well-preserved buried soil O horizons whose upper contacts can be dated by radiocarbon. In $\mathbf{d}$, similar subsidence, largely complete postseismic recovery, and slowly falling sea level result in minimal burial and later erosion of tidal marsh $\mathrm{O}$ horizons; buried soil $\mathrm{O}$ horizons are not preserved. Modified and reprinted from Nelson et al. [52], with permission from Elsevier

The differences in the RSL predictions during the Holocene from these two models is driven predominately by differences in the deglaciation histories of the Antarctic Ice sheet, with a larger total ice-volume equivalent sea-level contribution (26 m versus $13.6 \mathrm{~m}$ ) [62] and melting continuing until $1 \mathrm{ka}$ (compared to $4 \mathrm{ka}$ ) in the Bradley et al. [61] model (Online Resource 2). For the ICE model, we generated predictions for a suite of earth models to look at the impact of changes in lithosphere thickness and upper and lower mantle viscosity on RSL predictions [61]. Rates of past RSL change were derived from the GIA predictions by calculating the numerical derivative of each curve over 1-ka time intervals for an upper and lower range of rate values.

Within regions near-, intermediate-, and far-field from northern hemisphere ice sheets, we selected the longest records of prehistoric earthquakes preserved in coastal wetland stratigraphy to compare to the RSL histories and models. The selected studies used a standard set of criteria [13] to support their interpretations of coseismic and interseismic origin for the changes in coastal wetland stratigraphy. The key criteria used were the lateral extent of sharp stratigraphic contacts; the suddenness and amount of coseismic vertical deformation; the synchroneity of coseismic vertical deformation among regional sites; and the coincidence of tsunami deposits with sudden changes in stratigraphy. To plot prehistoric earthquake histories against RSL histories 
and models, we used calibrated radiocarbon age ranges $(2 \sigma)$ for earthquakes reported in the original publications (Online Resource 3).

\section{Case Study: Cascadia Subduction Zone}

Because the Cascadia subduction zone (Fig. 1a, b) has not experienced a great earthquake since the M8.8-9.2 Cascadia earthquake in $\mathrm{AD} 1700$ [63, 64], we must rely on paleoenvironmental reconstructions of changes in RSL to reconstruct the patterns, timing, and magnitudes of past earthquakes. Fortunately, the creation of sediment accommodation space by gradual Holocene RSL rise [7, 59, 65] along Cascadia's coasts has produced unusually complete stratigraphic archives of coseismic subsidence spanning thousands of years [12, 20, 45, 50, 51, 65-67]. There are, however, significant differences in the lengths of prehistoric earthquake records at sites formerly covered by LGM ice sheets, compared with those located south of the ice margin (Fig. 1a, b).

\section{Near-Field Region Sites at Cascadia}

RSL history in near-field regions closest to the subduction zone (e.g., western Vancouver Island) was strongly controlled by ice-unloading history [68], resulting in continuous RSL fall ( $\sim \mathrm{mm} /$ year) following a sealevel highstand at around $6 \mathrm{ka}$ (Figs. 1a and 4a, b) [59]. This RSL fall limited accommodation space, restricting the formation of coastal wetlands conducive to the preservation of stratigraphic evidence of earthquakes to the last $1 \mathrm{ka}$ [69]. As a result, widespread stratigraphic evidence of coseismic subsidence is limited to the AD 1700 great earthquake [70-72]. One of the few longer records ( 2500 years) of coseismic subsidence comes not from a coastal wetland, but from a study by Hutchinson et al. [73] that identified three tsunami deposits in a lake coincident with changes in lake salinity. Salinity changes were inferred to be the result of coseismic subsidence lowering the bedrock sill of the lake sufficiently for it to be breached by tidal waters in the decades to centuries following the earthquakes (Figs. 1a and 4c). Other stratigraphic records of coseismic subsidence on the coast of western Vancouver Island may have been eroded or elevated above sea level due to long-term net uplift, although older, elevated records have not been reported [70].

\section{Intermediate-Field Region Sites at Cascadia}

At Cascadia sites in the intermediate-field region (e.g., southern Washington and central Oregon), the combination of eustatic sea-level rise and local isostatic subsidence resulted in rapid RSL rise ( $>10 \mathrm{~mm} /$ year) prior to $\sim 7 \mathrm{ka}$. This was followed by slower rates of rise $(<3 \mathrm{~mm} /$ year $)$ to the present as eustatic sea-level rise slowed and glacioisostatic subsidence became the dominant control on RSL history (Figs. 1b and 5a-d) [59]. Continuous gradual RSL rise created ample accommodation space for the formation of widespread coastal wetlands, which, when suddenly submerged during earthquakes, produce millennial-scale stratigraphic records of coseismic subsidence [20, 50, 51, $66,74,75]$.

In southern Washington, the oldest coastal wetland deposits are dated to $\sim 5.3 \mathrm{ka}$ [49]. RSL rise at rates of $<3 \mathrm{~mm} /$ year thereafter allowed sediment and wetland vegetation to aggrade [76] and stratigraphic evidence of coseismic subsidence to be preserved [49, 77]. Up to ten instances of coseismic subsidence over the last $\sim 5.3 \mathrm{ka}$ are recorded in the coastal stratigraphy at John's River and Willapa Bay (Figs. 1b and 5e).

Sites along the central Oregon coast contain the longest stratigraphic records of coseismic subsidence preserved in a subduction zone setting [20, 50]. The RSL history here is similar to that of southern Washington, but at multiple sites in central Oregon (e.g., Coquille River, Sixes River), gradual ( $<3 \mathrm{~mm}$ /year) RSL rise began earlier ( $\sim 7 \mathrm{ka})$, (Figs. $1 \mathrm{~b}$ and $5 \mathrm{~b}, \mathrm{~d})$. This is likely due to long-term tectonic uplift on upper plate faults and folds in the area, which would have slowed rates of RSL rise in comparison to southern Washington (Fig. 6a, b) $[78,79]$. The early onset of low rates of RSL rise created the accommodation space necessary to preserve a 7-kalong stratigraphic record of 12 earthquake subsidence events at the Coquille River, Oregon [20], and a similar 6-ka-long record of 11 earthquakes at the Sixes River, Oregon (Fig. 5f, g) [50].

\section{Preservation of Earthquake Stratigraphy in Far-Field Regions}

Subduction zone coastlines in far-field regions that have recorded an RSL highstand during the Holocene, such as the Sunda, Chile, and Japan subduction zones, preserve only geographically limited, discontinuous stratigraphic records of coseismic subsidence or uplift (Figs. 1c-e, $7 \mathrm{a}-\mathrm{f}$, and $8 \mathrm{a}-\mathrm{h})[8,14,15,21,53-56,80,81]$. The RSL history at far-field sites has generally restricted stratigraphic records of coseismic subsidence or uplift to brief time windows of preservation during (1) periods of slow $(<1.5 \mathrm{~mm} /$ year) $\mathrm{RSL}$ rise prior to the $\mathrm{mid}$ Holocene highstand (6-3 ka), which created accommodation space, or (2) the last 1-3 ka when RSL was within $\sim 2 \mathrm{~m}$ of modern sea level, and therefore stratigraphic 


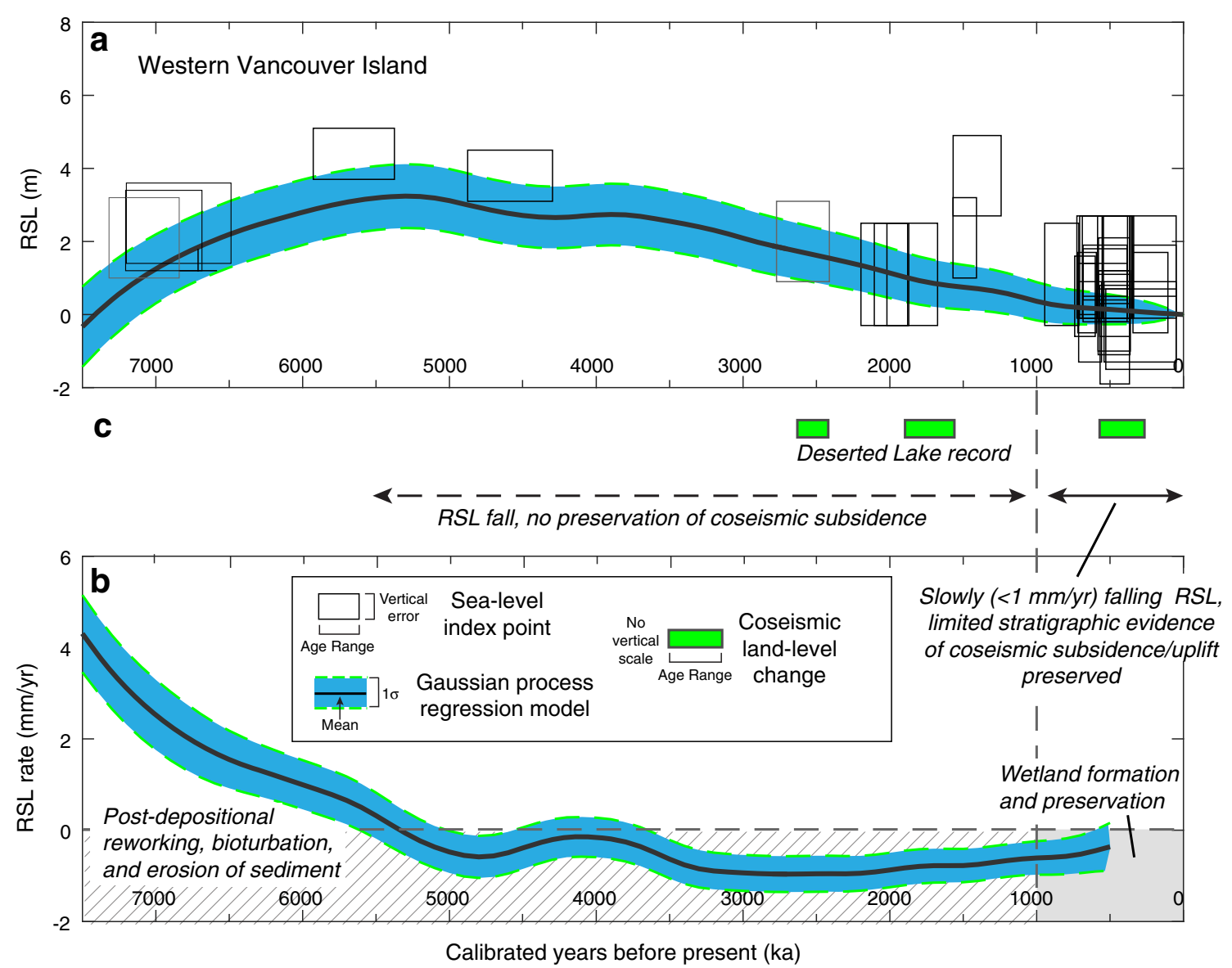

Fig. 4 a Selected relative sea-level (RSL) reconstruction from sites in western Vancouver Island (sites included in RSL reconstructions can be found in Engelhart et al. [59]. Elevations and interpretations of sea-level index points (including errors are from the original publication. All y-axes are RSL (in meters relative to present). Radiocarbon ages were calibrated at $2 \sigma . X$-axes are in 1000 calibrated years before present (ka). Blue curve shows the spatio-temporal empirical hierarchical model fit to the data, with the green dashed line representing $1 \sigma$ uncertainties. $\mathbf{b} 1 \mathrm{ka}$ average rates of RSL change calculated from the hierachical model from part a. Blue shaded area represents $1 \sigma$ uncertainties. Vertical dashed line denotes the beginning of preservation of earthquakes records. Horizontal dashed line shows the approximate rate below which stratigraphic records begin to be preserved. Gray shaded area beginning at $\sim 1$ ka highlights the period of continuous marsh formation and preservation. $\mathbf{c}$ Age ranges for three instances of coseismic subsidence preserved at Deserted Lake, western Vancouver Island [73] sequences have remained within the tidal frame (Great Diurnal Range is between 1 and $2 \mathrm{~m}$ at all our far-field sites) [82].

\section{Sunda Subduction Zone}

In northern and western Sumatra, GIA models predict high rates ( $>5 \mathrm{~mm} /$ year) of RSL rise from $\sim 12$ to $\sim 7 \mathrm{ka}$, followed by slowing rates of rise $(<1 \mathrm{~mm} / \mathrm{year})$ to an $\mathrm{RSL}$ highstand of $<1 \mathrm{~m}$ (northern Sumatra) and $\sim 3 \mathrm{~m}$ (western Sumatra) between 6 and $3 \mathrm{ka}$, and then gradual $(<1 \mathrm{~mm} /$ year) RSL fall until present (Fig. 7a, b). At two sites along the northern Aceh coast of Sumatra, Grand Pre et al. [83] and Kelsey et al. [56] document stratigraphic evidence of three instances of coseismic subsidence between 7 and $3.8 \mathrm{ka}$ (Figs. 1c and 7d). This window of preservation coincides with a period of gradual $\mathrm{RSL}$ rise $(<1 \mathrm{~mm} /$ year $)$ that created the accommodation space necessary for the mangrove-vegetated coastal plain to aggrade and preserve stratigraphic contacts marking repeated, coseismic subsidence and burial by tidal mud (Fig. 7a) [56]. Prior to $7 \mathrm{ka}$, rates of RSL rise were too high ( $>5 \mathrm{~mm} /$ year) for coastal wetland stratigraphy to form and be widely preserved [56]. A similar mid-Holocene record of coseismic subsidence was documented in western Sumatra in a lowland near Padang, where Dura et al. [8] found evidence of two instances of coseismic subsidence during a period of stable RSL between 4 and $3 \mathrm{ka}$ following the midHolocene highstand (Figs. 1c and 7b, e) [8]. Despite coral microatoll evidence of repeated coseismic vertical deformation in the late Holocene [84-86], no coastal stratigraphic evidence of deformation has been documented, probably because of erosion of coastal sediments during late Holocene RSL fall. 

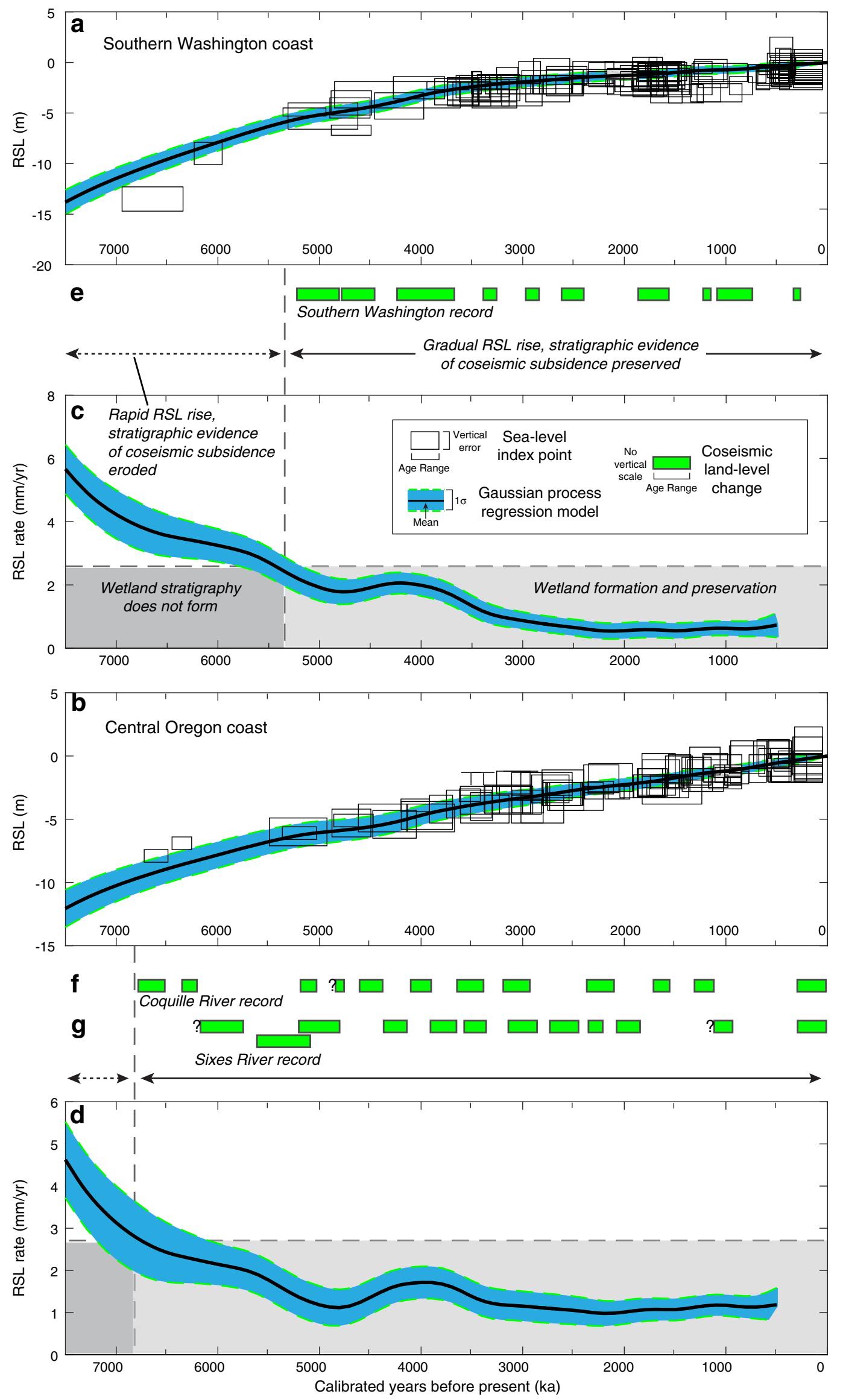
Fig. 5 Selected relative sea-level (RSL) reconstructions from southern Washington (a) State, USA, and central Oregon, USA (b) (sites included in RSL reconstructions can be found in Engelhart et al. [59]. All y-axes are RSL (in meters relative to present). Radiocarbon ages were calibrated at $2 \sigma . X$-axes are in 1000 calibrated years before present (ka). Blue curve shows the Gaussian process model fit to the data, with the green dashed line representing $1 \sigma$ uncertainties. $\mathbf{c}, \mathbf{d} 1 \mathrm{ka}$ average rates of RSL change calculated from the Gaussian process model from a and $\mathbf{b}$. Blue shaded area represents $1 \sigma$ uncertainties. Vertical dashed line denotes the beginning of preservation of earthquakes records. Horizontal dashed line shows the approximate rate below which stratigraphic records begin to be preserved. Gray shaded area beginning at $\sim 5.3 \mathrm{ka} \mathrm{(c)} \mathrm{and} \sim 7 \mathrm{ka}$ (d) highlights the period of wetland formation and preservation. e Age ranges for ten instances of coseismic subsidence at selected sites in southern Washington including Willapa Bay and John's River [49, 77]. f Age ranges for coseismic subsidence events at the Coquille River (12 earthquakes) [20] and g Sixes River (11 earthquakes) [50]. Question marks denote undated earthquakes

\section{Chile Subduction Zone}

In central and southern Chile, GIA models predict high rates $(>5 \mathrm{~mm} /$ year) of $\mathrm{RSL}$ rise from $\sim 12$ to $\sim 7 \mathrm{ka}$, followed by slowing rates of rise $(<1 \mathrm{~mm} /$ year $)$ to an RSL highstand of $\sim 3 \mathrm{~m}$ (central Chile) to $\sim 8 \mathrm{~m}$ (southern Chile) between 7 and $5 \mathrm{ka}$, and then gradual $(<1.5 \mathrm{~mm} /$ year) RSL fall until present (Fig. 7c and 8a). Dura et al.
[54] found a mid-Holocene record of repeated coseismic uplift in a former coastal marsh at Quintero north of Valparaiso, central Chile, which formed during gradual ( $<1 \mathrm{~mm} /$ year) RSL rise leading up to the mid-Holocene highstand, the shorelines of which now lie $\sim 2 \mathrm{~km}$ inland (Fig. 1d). Beneath this remnant marsh, stratigraphy shows evidence of six instances of coseismic uplift between $6.2 \mathrm{ka}$ - when rising RSL slowed and marsh sedimentation began-and $3.7 \mathrm{ka}$-when RSL fall stranded the marsh beyond the reach of tides (Fig. 7c, f) [54]. Although multiple historical $>\mathrm{M} 8$ earthquakes producing coseismic uplift have occurred along the central Chile coast, no stratigraphic evidence of the events has been documented [54].

In southern Chile, coastal stratigraphic records of past earthquakes are limited to the last 2 ka (Fig. 8a) [53, 87, 88]. At the Maullin estuary, Cisternas et al. [14] documented a $\sim 2$-ka-long record of seven buried soil contacts marking repeated coseismic subsidence (Figs. 1d and 8e). At Chiloe Island, Garrett et al. [21] found a 1-ka-long record of coseismic subsidence that correlated with the four youngest subsidence events at Maullin (Fig. 1d). The stratigraphic sections at both sites in southern Chile are $<1.5 \mathrm{~m}$ thick and preserved within the $\sim 2-\mathrm{m}$ modern
Fig. 6 a Plots of the rate of RSL change between 6 and $7 \mathrm{ka}$ generated by the spatio-temporal empirical hierarchical model for sites along the Cascadia subduction zone. Diamonds represent the sites used to produce the RSL rise field. Data used in the model can be found in Engelhart et al. [59]. b RSL rise field (showing RSL rates) between 3 and $4 \mathrm{ka}$
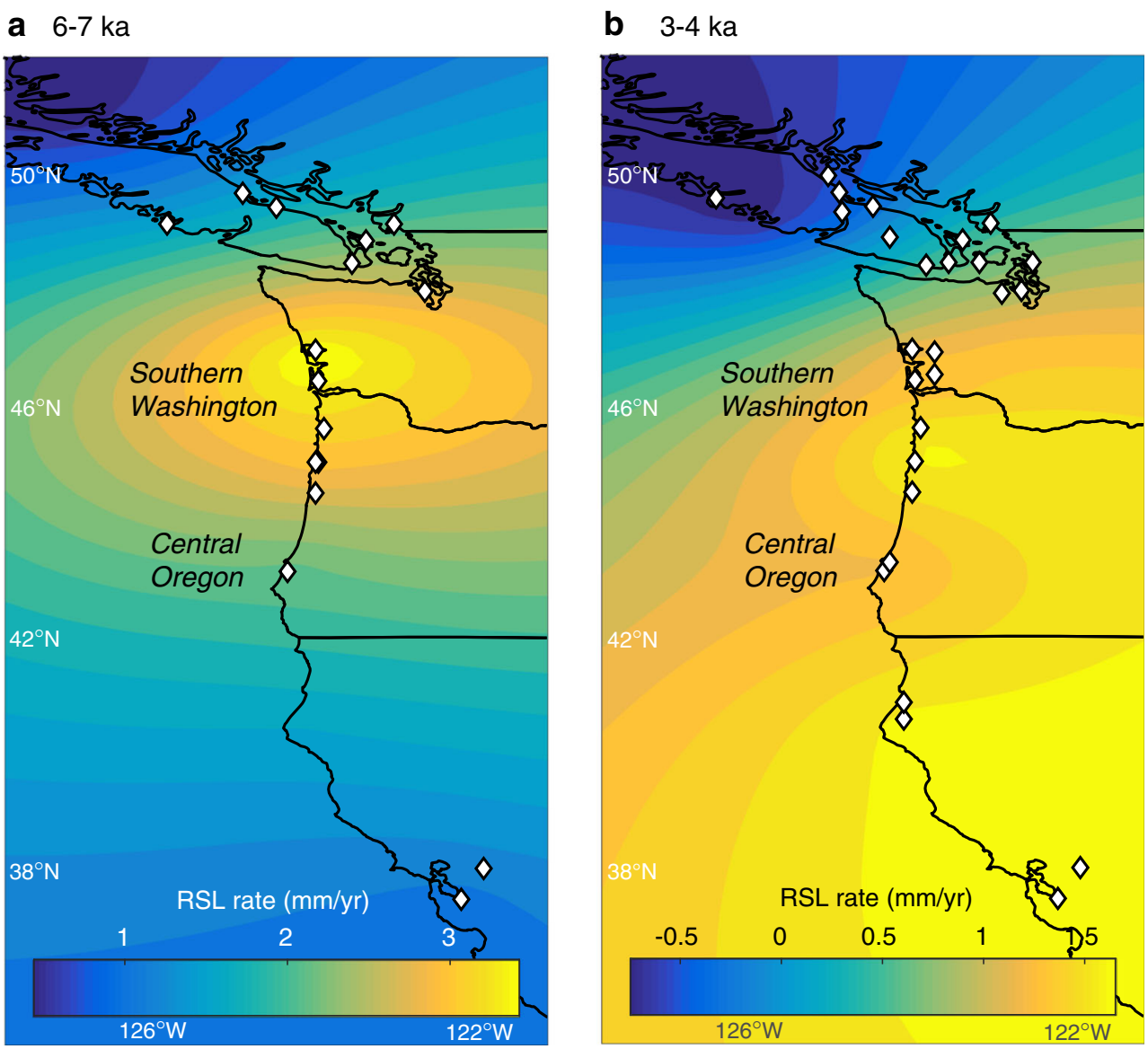
Fig. 7 GIA model predictions of the RSL history at prehistoric earthquake study sites in northern Sumatra (Aceh) (a), central Sumatra (Padang) (b), and central Chile (Quintero) (c). The ICE6G_C (VM6) model (dashed line) was generated following the methods of Roy and Peltier [33], and the range of ICE model predictions (blue lines) was generated following the methods of Bradley et al. [61] by varying the lithosphere thickness and upper and lower mantle viscosity in the earth model. Blue lines (from top to bottom in the figure legend) represent earth models 71p510, 96p510, 120p510, 96p110, 96110, 96p51, 96p550, and 96p28 (defined in Online Resource 1). d Age ranges for three instances of coseismic subsidence at two sites in northern Sumatra [56]. e Age ranges for two instances of coseismic subsidence in western Sumatra [8]. f Age ranges for six instances of coseismic uplift in central Chile [54]
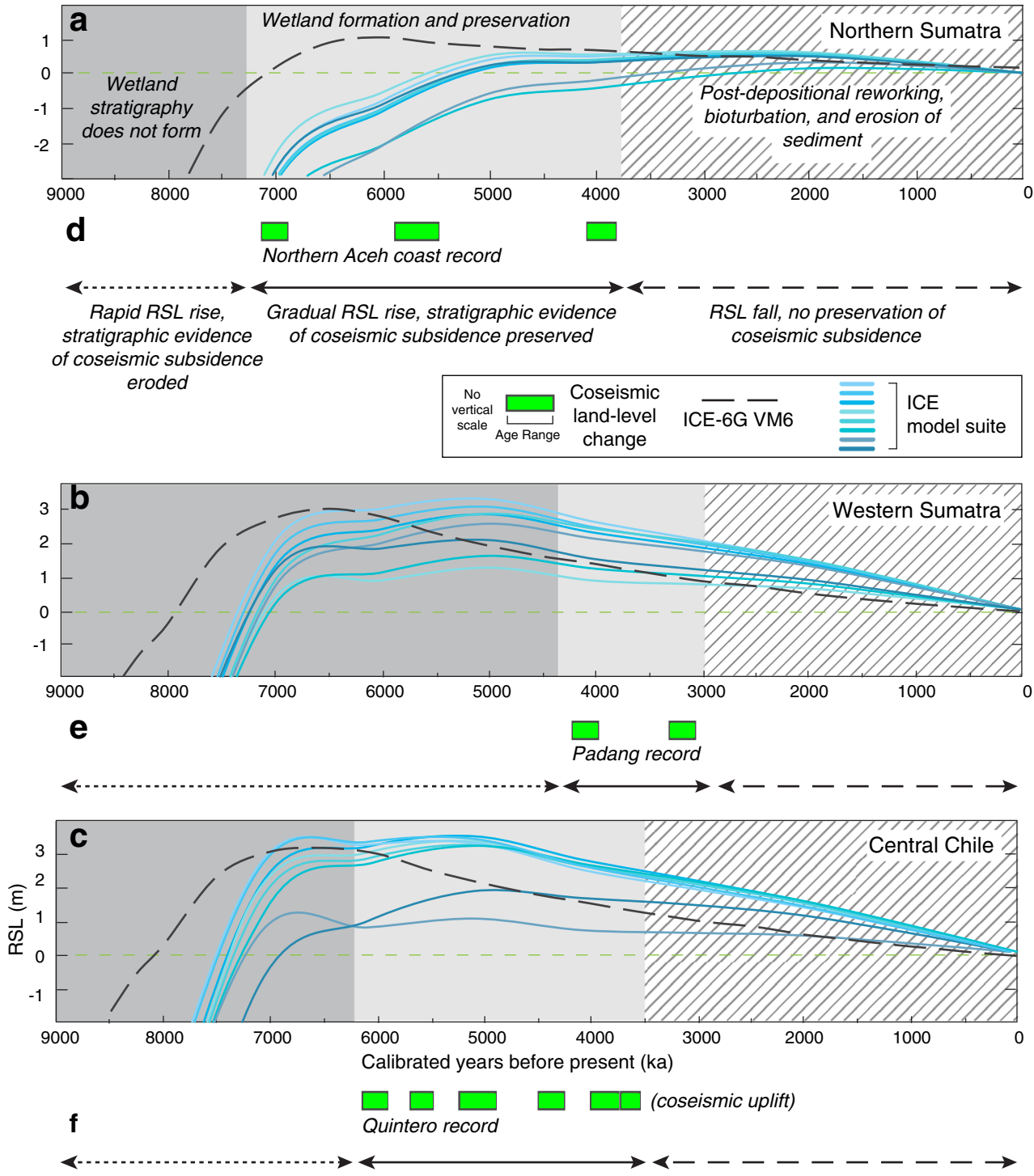

tidal range. However, Garrett et al. [21] noted the occurrence of high marsh soils at elevations below modern mean sea level, implying RSL rise during the last $1 \mathrm{ka}$. This is in contrast to the late Holocene emergence noted in studies to the north [14, 53, 55, 87-89] and in our GIA predictions. Garrett et al. [21] suggest that net tectonic subsidence of Chiloe Island, or glacio-isostatic subsidence related to the Patagonian Ice Sheet and not considered in current GIA models, may have caused RSL rise during the last $1 \mathrm{ka}$.

\section{Japan Subduction Zone}

At the Sendai Plain, the Tokyo metropolitan area, and eastern Hokkaido, Japan, GIA models predict high rates ( $>5 \mathrm{~mm} /$ year) of RSL rise from $\sim 12$ to $\sim 7 \mathrm{ka}$, followed by slowing rates of rise $(<1 \mathrm{~mm} /$ year $)$ to an $\mathrm{RSL}$ highstand of $\sim 3 \mathrm{~m}$ between 6 and $4 \mathrm{ka}$, and then gradual $(<1 \mathrm{~mm} /$ year) RSL fall until present (Fig. 8b-d). The prograding beach ridge sequences that formed during late Holocene RSL fall in the Sendai Plain contain limited evidence of coseismic vertical deformation (Fig. 1e and 8b) [17]. Sawai et al. [17] documented evidence of coseismic subsidence associated with two tsunami sand beds (dated to $\sim 1.5$ and $\sim 1 \mathrm{ka}$ ) preserved within the stratigraphy of a sheltered lowland in Odaka (Fig. 8f). Further south, in the Tokyo metropolitan area, stratigraphic records of coseismic vertical deformation are limited to the last $\sim 1 \mathrm{ka}$ (Fig. 8c). At the Miura Peninsula, Shimazaki et al. [90] found evidence of three instances of coseismic uplift that abruptly changed a shallow subtidal bay environment into a tidal flat (Fig. 8g). The three uplift events occurred during three historical Kanto earthquakes in AD 1923, 1703, and 
Fig. 8 GIA predictions of the RSL history at prehistoric earthquake study sites in southern Chile (a), the Sendai Plain (b), the Tokyo metropolitan area (c), and eastern Hokkaido (d). Models were generated following the methods of Roy and Peltier [33] and Bradley et al. [61] as described in Fig 7. e Age ranges for seven instances of coseismic subsidence in southern Chile (Maullin) [14]. f Age ranges for two instances of coseismic subsidence in the Sendai Plain (Odaka) [17]. g Age ranges for three instances of coseismic uplift in the Tokyo metropolitan area (Miura Peninsula) [90]. h Age ranges for four [80,93] and six [15] instances of postseismic uplift in eastern Hokkaido (Onnetoh and Kiritappu)
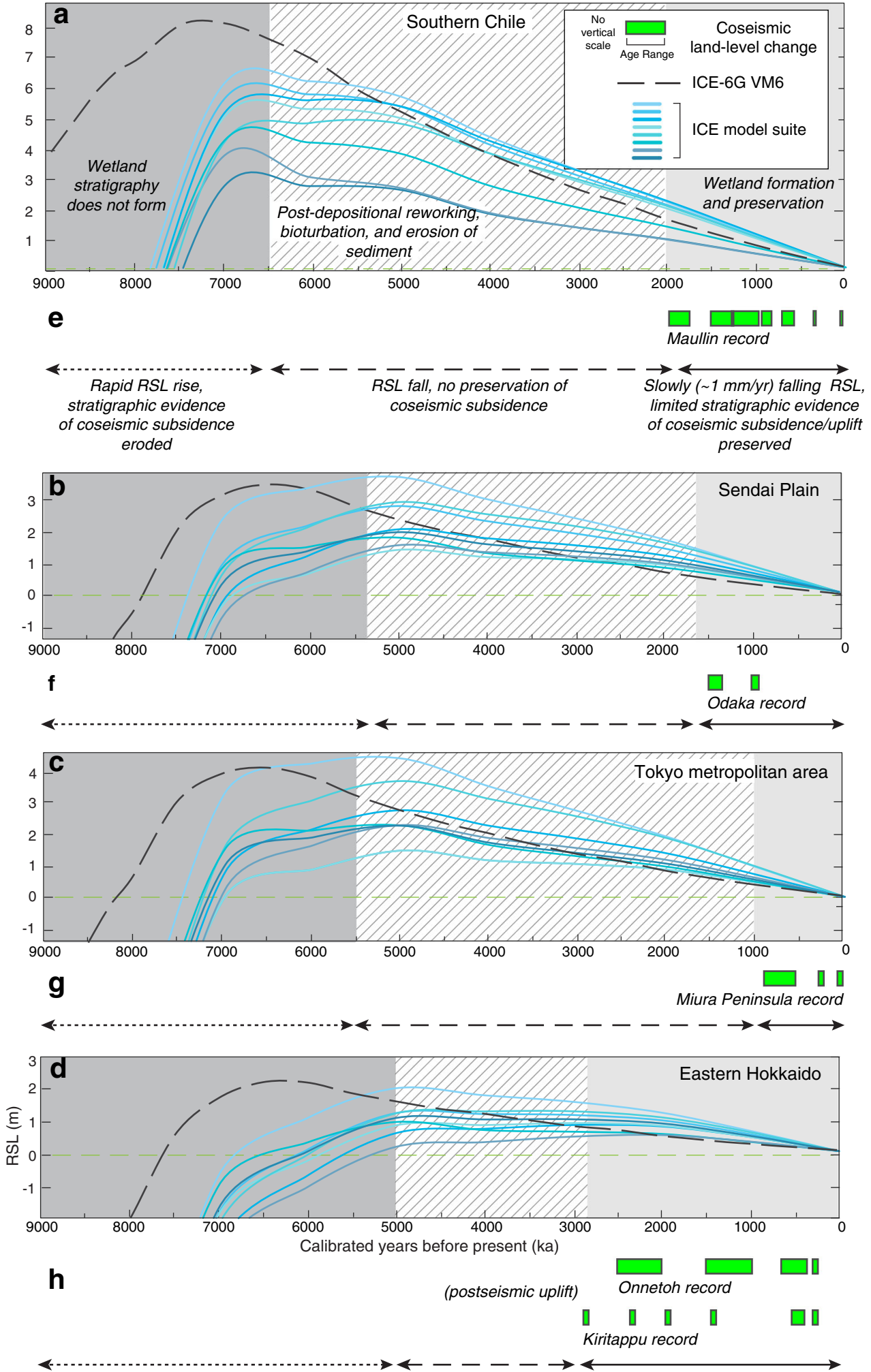

1060-1400. Similar to southern Chile, the stratigraphic sections in the Sendai Plain and the Tokyo Metropolitan area are within the modern tidal range $(\sim 1.5 \mathrm{~m})$.
Stratigraphy beneath multiple coastal wetlands fringing estuaries in eastern Hokkaido, northern Japan, contains evidence of up to six postseismic uplift events in the last $3 \mathrm{ka}$ (Figs. 1e and $8 \mathrm{~h}[15,81,91,92]$. Each uplift event is marked by a 
change between a tidal flat mud and a freshwater marsh, signaling at least $1 \mathrm{~m}$ of slow, postseismic uplift following earthquakes larger than any in the region's written history [91, 93]. The tide gauge records in eastern Hokkaido, northern Japan, display submergence of $8-10 \mathrm{~mm} /$ year over the last $\sim 100$ years [81]. This pronounced subsidence over the twentieth century has been ascribed to interseismic strain accumulation that has not been reversed by recent earthquakes [81]. Infrequent postseismic uplift may help reconcile eastern Hokkaido's twentieth century submergence with its stratigraphic evidence of long-term RSL fall during the Holocene $[81,93]$.

\section{Conclusions}

As geologists have conducted prehistoric earthquake studies at subduction zone coasts with variable long-term RSL histories, it has become clear that complete, millennial-scale records of prehistoric earthquakes are rare. The length and completeness of coastal stratigraphic records of past earthquakes is linked to the accommodation space provided by gradually rising ( $<3 \mathrm{~mm} /$ year) long-term RSL, assuming sufficient sediment supply. Gradual RSL rise produces the accommodation space necessary for the formation and preservation of coastal wetland soils, whose upper or lower stratigraphic contacts serve as the most effective markers of coseismic vertical deformation. Faster ( $>3 \mathrm{~mm} /$ year) rates of rise generally prevent the formation of widespread coastal wetlands, while falling RSL leads to erosion of coastal wetland stratigraphy. Understanding the interplay among RSL change and coastal processes along subduction zones will help focus field research and improve interpretations of stratigraphic evidence of coseismic subsidence or uplift.

- At subduction zone sites in near-field regions (i.e., western Vancouver Island), RSL fall over the last $\sim 6$ ka has limited stratigraphic evidence of past earthquakes to the last $1 \mathrm{ka}$.

- At subduction zone sites in intermediate-field regions (i.e., southern Washington and central Oregon), gradual RSL rise over the last 7-5 ka has produced widespread coastal wetland stratigraphy that contains the longest $(>5 \mathrm{ka})$ documented stratigraphic records of repeated coseismic subsidence. Subtle differences in the onset of gradual ( $<3 \mathrm{~mm} /$ year) RSL rise influence the length of stratigraphic records of coseismic subsidence in central Oregon $(\sim 7 \mathrm{ka})$ and southern Washington $(\sim 5 \mathrm{ka})$.

- At subduction zone sites in far-field regions such as Sumatra and central Chile, gradual $(<1.5 \mathrm{~mm} /$ year $)$ RSL rise leading up to the mid-Holocene highstand $(6-3 \mathrm{ka})$ provided the accommodation space necessary for coastal wetlands to form and for prehistoric earthquake evidence to be preserved. In southern Chile and Japan, prehistoric earthquake records are limited to the last $1-3 \mathrm{ka}$, when RSL was within $2 \mathrm{~m}$ of modern sea level, and thus within the tidal frame, preserving geographically limited coastal wetlands despite slowly falling RSL. Subtle differences in RSL influence the length of these far-field records.

Acknowledgments This work was supported by funding from National Science Foundation awards to TD (EAR-439021), SEE (EAR1419844), BPH (EAR-1357756, 1419824, 0809392), and REK (ARC1203415). TD would like to thank Antonio Osa for his unwavering support and encouragement (AMQPLV). We thank Alan Nelson and Harvey Kelsey for constructive reviews that improved the manuscript. This paper is a contribution to IGCP project 639 and PALSEA2. MV contributes to the the A*MIDEX project ( ${ }^{\circ}$ ANR-11-IDEX-0001-02). On behalf of all authors, the corresponding author states that there is no conflict of interest.

\section{References}

1. Clark JA, Farrell WE, Peltier WR. Global changes in postglacial sea level: a numerical calculation. Quat Res. 1978;9(3):265-87.

2. Mitrovica JX, Milne GA. On the origin of late Holocene sea-level highstands within equatorial ocean basins. Quat Sci Rev. 2002;21(20-22):2179-90.

3. Peltier WR. Global glacial isostasy and the surface of the ice-age Earth: the ICE-5G (VM2) model and GRACE. Annu Rev Earth Planet Sci. 2004;32:111-49.

4. Rampino MR, Sanders JE. Episodic growth of Holocene tidal marshes in the northeastern United States: a possible indicator of eustatic sea-level fluctuations. Geology. 1981;9(2):63-7.

5. Horton BP, Engelhart SE, Kemp AC, Sawai Y. 14.25 Microfossils in tidal settings as indicators of sea-level change, paleoearthquakes, tsunamis, and tropical cyclones A2 - Shroder, John F. In: Treatise on geomorphology [Internet]. San Diego: Academic Press; 2013. p. 292-314. Available from: http://www.sciencedirect. com/science/article/pii/B9780123747396003948.

6. Nikitina D, Kemp AC, Engelhart SE, Horton BP, Hill DF, Kopp RE. Sea-level change and subsidence in the Delaware Estuary during the last 2200 years. Estuar Coast Shelf Sci. 2015;164:506-19.

7. Long AJ, Shennan I. Models of rapid relative sea-level change in Washington and Oregon, USA. The Holocene. 1998;8(2):129-42.

8. Dura T, Rubin CM, Kelsey HM, Horton BP, Hawkes A, Vane CH, et al. Stratigraphic record of Holocene coseismic subsidence, Padang, West Sumatra. J Geophys Res Solid Earth. 2011; 116(B11).

9. Kirwan ML, Megonigal JP. Tidal wetland stability in the face of human impacts and sea-level rise. Nature. 2013;504(7478):53-60.

10. Kemp AC, Horton BP, Engelhart SE. SEA-LEVELS, LATE QUATERNARY | Late quaternary relative sea-level changes at mid-latitudes A2-Elias, Scott A. In: Mock CJ, editor. Encyclopedia of quaternary science (second edition) [Internet]. Amsterdam: Elsevier; 2013. p. 489-94. Available from: http://www.sciencedirect.com/science/article/ pii/B9780444536433001400

11. Khan NS, Ashe E, Shaw TA, Vacchi M, Walker J, Peltier WR, et al. Holocene relative sea-level changes from near-, intermediate-, and far-field locations. Curr Clim Chang Rep. 2015;1(4):247-62.

12. Atwater BF. Evidence for great Holocene earthquakes along the outer coast of Washington State. Science. 1987;236(4804):942-4.

13. Nelson AR, Shennan I, Long AJ. Identifying coseismic subsidence in tidal-wetland stratigraphic sequences at the Cascadia subduction 
zone of western North America. J Geophys Res Solid Earth. 1996;101(B3):6115-35.

14. Cisternas M, Atwater BF, Torrejón F, Sawai Y, Machuca G, Lagos M, et al. Predecessors of the giant 1960 Chile earthquake. Nature. 2005;437(7057):404-7.

15. Kelsey H, Satake K, Sawai Y, Sherrod B, Shimokawa K, Shishikura M. Recurrence of postseismic coastal uplift, Kuril subduction zone, Japan. Geophys Res Lett. 2006;33(13).

16. Rhodes B, Tuttle M, Horton B, Doner L, Kelsey H, Nelson A, et al. Paleotsunami research. Eos. 2006;87(21):205.

17. Sawai Y, Namegaya Y, Okamura Y, Satake K, Shishikura M. Challenges of anticipating the 2011 Tohoku earthquake and tsunami using coastal geology. Geophys Res Lett. 2012; 39(21).

18. Sieh K. Daly, McKinnon, E, Pilarczyk JE, Chiang H-W, Horton BP, et al. Penultimate predecessors of the 2004 Indian Ocean tsunami in Aceh, Sumatra: stratigraphic, and historical evidence. J Geophys Res Solid Earth. 2015;120:308-25.

19. Plafker G. Tectonic deformation associated with the 1964 Alaska earthquake. Science. 1965;148(3678):1675-87.

20. Witter RC, Kelsey HM, Hemphill-Haley E. Great Cascadia earthquakes and tsunamis of the past 6700 years, Coquille River estuary, southern coastal Oregon. Geol Soc Am Bull. 2003;115(10):1289306.

21. Garrett E, Shennan I, Woodroffe SA, Cisternas M, Hocking EP, Gulliver P. Reconstructing paleoseismic deformation, 2: 1000 years of great earthquakes at Chucalén, south central Chile. Quat Sci Rev. 2015;113:112-22.

22. Dutton A, Carlson AE, Long AJ, Milne GA, Clark PU, DeConto R, et al. Sea-level rise due to polar ice-sheet mass loss during past warm periods. Science. 2015;349(6244):aaa4019.

23. Peltier WR. On eustatic sea level history: last glacial maximum to Holocene. Quat Sci Rev. 2002;21(1):377-96.

24. Lambeck K, Purcell A, Johnston P, Nakada M, Yokoyama Y. Water-load definition in the glacio-hydro-isostatic sea-level equation. Quat Sci Rev. 2003;22(2):309-18.

25. Lambeck K, Rouby H, Purcell A, Sun Y, Sambridge M. Sea level and global ice volumes from the last glacial maximum to the Holocene. Proc Natl Acad Sci. 2014;111(43):15296-303.

26. Carlson AE, LeGrande AN, Oppo DW, Came RE, Schmidt GA, Anslow FS, et al. Rapid early Holocene deglaciation of the Laurentide ice sheet. Nat Geosci. 2008;1(9):620-4.

27. Bentley MJ, Fogwill CJ, Le Brocq AM, Hubbard AL, Sugden DE, Dunai TJ, et al. Deglacial history of the West Antarctic Ice Sheet in the Weddell Sea embayment: constraints on past ice volume change. Geology. 2010;38(5):411-4.

28. Milne GA, Gehrels WR, Hughes CW, Tamisiea ME. Identifying the causes of sea-level change. Nat Geosci. 2009;2(7):471-8.

29. Simon KM, James TS, Forbes DL, Telka AM, Dyke AS, Henton JA. A relative sea-level history for Arviat, Nunavut, and implications for Laurentide Ice Sheet thickness west of Hudson Bay. Quat Res. 2014;82(1):185-97.

30. Shugar DH, Walker IJ, Lian OB, Eamer JB, Neudorf C, McLaren $\mathrm{D}$, et al. Post-glacial sea-level change along the Pacific coast of North America. Quat Sci Rev. 2014;97:170-92.

31. Peltier WR. Global sea level rise and glacial isostatic adjustment: an analysis of data from the east coast of North America. Geophys Res Lett. 1996;23(7):717-20.

32. Engelhart SE, Horton BP, Douglas BC, Peltier WR, Törnqvist TE. Spatial variability of late Holocene and 20th century sea-level rise along the Atlantic coast of the United States. Geology. 2009;37(12): 1115-8.

33. Roy K, Peltier WR. Glacial isostatic adjustment, relative sea level history and mantle viscosity: reconciling relative sea level model predictions for the US east coast with geological constraints. Geophys J Int. 2015;201(2):1156-81.
34. Engelhart SE, Horton BP. Holocene sea level database for the Atlantic coast of the United States. Quat Sci Rev. 2012;54:12-25.

35. Lambeck K, Nakada M. Late Pleistocene and Holocene sea-level change along the Australian coast. Palaeogeogr Palaeoclimatol Palaeoecol. 1990;89(1-2):143-76.

36. Rostami K, Peltier WR, Mangini A. Quaternary marine terraces, sea-level changes and uplift history of Patagonia, Argentina: comparisons with predictions of the ICE-4G (VM2) model of the global process of glacial isostatic adjustment. Quat Sci Rev. 2000;19(14): 1495-525.

37. Pluet J, Pirazzoli PA. World atlas of Holocene sea-level changes. Vol. 58. Elsevier; 1991

38. Fleming K, Johnston P, Zwartz D, Yokoyama Y, Lambeck K, Chappell J. Refining the eustatic sea-level curve since the Last Glacial Maximum using far-and intermediate-field sites. Earth Planet Sci Lett. 1998;163(1):327-42.

39. Reed DJ. The response of coastal marshes to sea-level rise: survival or submergence? Earth Surf Process Landf. 1995;20(1):39-48.

40. Morris JT, Sundareshwar PV, Nietch CT, Kjerfve B, Cahoon DR. Responses of coastal wetlands to rising sea level. Ecology. 2002;83(10):2869-77.

41. Kirwan ML, Guntenspergen GR, D’Alpaos A, Morris JT, Mudd SM, Temmerman S. Limits on the adaptability of coastal marshes to rising sea level. Geophys Res Lett. 2010;37(23).

42. Pratolongo PD, Kirby JR, Plater A, Brinson MM. Temperate coastal wetlands: morphology, sediment processes, and plant communities. Coast Wetl Integr Ecosyst Approach 2009; 975.

43. Atwater BF, Hemphill-Haley E. Recurrence intervals for great earthquakes of the past 3,500 years at northeastern Willapa Bay, Washington. USGPO; Information Services [distributor]; 1997.

44. Shennan I, Hamilton S. Coseismic and pre-seismic subsidence associated with great earthquakes in Alaska. Quat Sci Rev. 2006;25(1):1-8

45. Milker Y, Nelson AR, Horton BP, Engelhart SE, Bradley L-A, Witter RC. Differences in coastal subsidence in southern Oregon (USA) during at least six prehistoric megathrust earthquakes. Quat Sci Rev. 2016;142:143-63.

46. Neubauer SC. Contributions of mineral and organic components to tidal freshwater marsh accretion. Estuar Coast Shelf Sci. 2008;78(1):78-88.

47. Briggs RW, Engelhart SE, Nelson AR, Dura T, Kemp AC, Haeussler PJ, et al. Uplift and subsidence reveal a nonpersistent megathrust rupture boundary (Sitkinak Island, Alaska). Geophys Res Lett. 2014;41(7):2289-96.

48. Shennan I, Bruhn R, Plafker G. Multi-segment earthquakes and tsunami potential of the Aleutian megathrust. Quat Sci Rev. 2009;28(1):7-13.

49. Shennan I, Long AJ, Rutherford MM, Green FM, Innes JB, Lloyd $\mathrm{JM}$, et al. Tidal marsh stratigraphy, sea-level change and large earthquakes, I: a 5000 year record in Washington, USA. Quat Sci Rev. 1996;15(10):1023-59.

50. Kelsey HM, Witter RC, Hemphill-Haley E. Plate-boundary earthquakes and tsunamis of the past $5500 \mathrm{yr}$, Sixes River estuary, southern Oregon. Geol Soc Am Bull. 2002;114(3):298-314.

51. Nelson AR, Sawai Y, Jennings AE, Bradley L-A, Gerson L, Sherrod BL, et al. Great-earthquake paleogeodesy and tsunamis of the past 2000 years at Alsea Bay, central Oregon coast, USA. Quat Sci Rev. 2008;27(7):747-68.

52. Nelson AR. SEA-LEVELS, LATE QUATERNARY | Tectonics and relative sea-level change A2-Elias, Scott A. In: Mock CJ, editor. Encyclopedia of quaternary science (second edition) [Internet]. Amsterdam: Elsevier; 2013. p. 503-19. Available from: http://www.sciencedirect.com/science/article/pii/B978044453 6433001412 
53. Nelson AR, Kashima K, Bradley L-A. Fragmentary evidence of greatearthquake subsidence during holocene emergence, Valdivia estuary, South Central Chile. Bull Seismol Soc Am. 2009;99(1):71-86.

54. Dura T, Cisternas M, Horton BP, Ely LL, Nelson AR, Wesson RL, et al. Coastal evidence for Holocene subduction-zone earthquakes and tsunamis in central Chile. Quat Sci Rev. 2015;113:93-111.

55. Ely LL, Cisternas M, Wesson RL, Dura T. Five centuries of tsunamis and land-level changes in the overlapping rupture area of the 1960 and 2010 Chilean earthquakes. Geology. 2014;42(11):995-8.

56. Kelsey HM, Engelhart SE, Pilarczyk JE, Horton BP, Rubin CM, Daryono MR, et al. Accommodation space, relative sea level, and the archiving of paleo-earthquakes along subduction zones. Geology. 2015;43(8):675-8.

57. Shennan I, Long AJ, Horton BP. Handbook of sea-level research. John Wiley \& Sons; 2015.

58. Shennan I, Horton B. Holocene land-and sea-level changes in Great Britain. J Quat Sci. 2002;17(5-6):511-26.

59. Engelhart SE, Vacchi M, Horton BP, Nelson AR, Kopp RE. A sealevel database for the Pacific coast of central North America. Megathrust Earth Sea-Level Chang Tribute George Plafker. 2015;113:78-92.

60. Kopp RE, Kemp AC, Bitterman K, Horton BP, Donnelly JP, Gehrels WR, et al. Temperature-driven global sea-level variability in the Common Era. Proc Natl Acad Sci. 2016;113(11):E1434-41.

61. Bradley SL, Milne GA, Horton BP, Zong Y. Modelling sea level data from China and Malay-Thailand to estimate Holocene ice-volume equivalent sea level change. Quat Sci Rev. 2016;137:54-68.

62. Argus DF, Peltier WR, Drummond R, Moore AW. The Antarctica component of postglacial rebound model ICE-6G_C (VM5a) based on GPS positioning, exposure age dating of ice thicknesses, and relative sea level histories. Geophys J Int. 2014;198(1):537-63.

63. Heaton TH, Kanamori H. Seismic potential associated with subduction in the northwestern United States. Bull Seismol Soc Am. 1984;74(3):933-41.

64. McCrory PA, Blair JL, Waldhauser F, Oppenheimer DH. Juan de Fuca slab geometry and its relation to Wadati-Benioff zone seismicity. J Geophys Res Solid Earth. 2012; 117(B9).

65. Hutchinson I. Holocene sea level change in the Pacific Northwest: a catalogue of radiocarbon dates and an atlas of regional sea-level curves. Institute of Quaternary Research, Simon Fraser University; 1992.

66. Atwater BF. Geologic evidence for earthquakes during the past 2000 years along the Copalis River, southern coastal Washington. J Geophys Res Solid Earth. 1992;97(B2):1901-19.

67. Kelsey HM, Nelson AR, Hemphill-Haley E, Witter RC. Tsunami history of an Oregon coastal lake reveals a $4600 \mathrm{yr}$ record of great earthquakes on the Cascadia subduction zone. Geol Soc Am Bull. 2005;117(7-8):1009-32.

68. Dallimore A, Enkin RJ, Pienitz R, Southon JR, Baker J, Wright CA, et al. Postglacial evolution of a Pacific coastal fjord in British Columbia, Canada: interactions of sea-level change, crustal response, and environmental fluctuations-results from MONA core MD02-2494. This article is one of a series of papers published in this special issue on the theme Polar Climate Stability Network. Can J Earth Sci. 2008;45(11):1345-62.

69. Benson BE, Grimm KA, Clague JJ. Tsunami deposits beneath tidal marshes on northwestern Vancouver Island, British Columbia. Quat Res. 1997;48(2):192-204.

70. Clague JJ, Bobrowsky PT. Evidence for a large earthquake and tsunami 100-400 years ago on western Vancouver Island, British Columbia. Quat Res. 1994;41(2):176-84.

71. Guilbault J-P, Clague JJ, Lapointe M. Amount of subsidence during a late Holocene earthquake - evidence from fossil tidal marsh foraminifera at Vancouver Island, west coast of Canada. Palaeogeogr Palaeoclimatol Palaeoecol. 1995;118(1):49-71.
72. Guilbault J-P, Clague JJ, Lapointe M. Foraminiferal evidence for the amount of coseismic subsidence during a late Holocene earthquake on Vancouver Island, west coast of Canada. Quat Sci Rev. 1996;15(8):913-37.

73. Hutchinson I, Guilbault J-P, Clague JJ, Bobrowsky PT. Tsunamis and tectonic deformation at the northern Cascadia margin: a 3000year record from Deserted Lake, Vancouver Island, British Columbia, Canada. The Holocene. 2000;10(4):429-39.

74. Darienzo ME, Peterson CD, Clough C. Stratigraphic evidence for great subduction-zone earthquakes at four estuaries in northern Oregon, USA. J Coast Res. 1994;850-76.

75. Nelson AR. Discordant $14 \mathrm{C}$ ages from buried tidal-marsh soils in the Cascadia subduction zone, southern Oregon coast. Quat Res. 1992;38(1):74-90.

76. Peterson CD. Holocene sedimentary framework of Grays Harbor basin, Washington. 1992.

77. Atwater BF, Tuttle MP, Schweig ES, Rubin CM, Yamaguchi DK, Hemphill-Haley E. Earthquake recurrence inferred from paleoseismology. Quat Period U S. 2003; 331-50.

78. Kelsey HM. Late Quaternary deformation of marine terraces on the Cascadia subduction zone near Cape Blanco. Oregon Tectonics. 1990;9(5):983-1014.

79. Kelsey HM, Engebretson DC, Mitchell CE, Ticknor RL. Topographic form of the Coast Ranges of the Cascadia margin in relation to coastal uplift rates and plate subduction. J Geophys Res Solid Earth. 1994;99(B6):12245-55.

80. Sawai Y. Evidence for 17th-century tsunamis generated on the Kuril-Kamchatka subduction zone, Lake Tokotan, Hokkaido, Japan. J Asian Earth Sci. 2002;20(8):903-11.

81. Atwater BF, Furukawa R, Hemphill-Haley E, Ikeda Y, Kashima K, Kawase K, et al. Seventeenth-century uplift in eastern Hokkaido, Japan. The Holocene. 2004;14(4):487-501.

82. United Kingdom Hydrographic Office. Admiralty Tide Tables: Pacific Ocean. Vol. 4. United Kingdom Hydrographic Office; 2016.

83. Grand Pre CA, Horton BP, Kelsey HM, Rubin CM, Hawkes AD, Daryono MR, et al. Stratigraphic evidence for an early Holocene earthquake in Aceh, Indonesia. Quat Sci Rev. 2012;54:142-51.

84. Sieh K, Natawidjaja DH, Meltzner AJ, Shen C-C, Cheng H, Li K-S, et al. Earthquake supercycles inferred from sea-level changes recorded in the corals of West Sumatra. Science. 2008;322(5908): 1674-8.

85. Briggs RW, Sieh K, Amidon WH, Galetzka J, Prayudi D, Suprihanto I, et al. Persistent elastic behavior above a megathrust rupture patch: Nias island, West Sumatra. J Geophys Res Solid Earth. 2008; 113(B12).

86. Meltzner AJ, Sieh K, Chiang H-W, Shen C-C, Suwargadi BW, Natawidjaja DH, et al. Coral evidence for earthquake recurrence and an AD 1390-1455 cluster at the south end of the 2004 AcehAndaman rupture. J Geophys Res Solid Earth. 2010; 115(B10).

87. Atwater BF, Núñez HJ, Vita-Finzi C. Net late Holocene emergence despite earthquake-induced submergence, south-Central Chile. Quat Int. 1992;15:77-85.

88. Bartsch-Winkler S, Schmoll HR. Evidence for Late Holocene relative sea-level fall from reconnaissance stratigraphical studies in an area of earthquake - Southern Chile. Tecton Controls Signat Sediment Successions Spec Publ 20 IAS. 2009;40:91.

89. Hong I, Dura T, Ely LL, Horton BP, Nelson AR, Cisternas M, et al. A 600-year-long stratigraphic record of tsunamis in south-central Chile. Holocene. 2016; 0959683616646191.

90. Shimazaki K, Kim HY, Chiba T, Satake K. Geological evidence of recurrent great Kanto earthquakes at the Miura Peninsula, Japan. J Geophys Res Solid Earth. 2011; 116(B12).

91. Sawai Y, Nasu H, Yasuda Y. Fluctuations in relative sea-level during the past $3000 \mathrm{yr}$ in the Onnetoh estuary, Hokkaido, northern Japan. J Quat Sci. 2002;17(5-6):607-22. 
92. Sawai Y, Satake K, Kamataki T, Nasu H, Shishikura M, Atwater $\mathrm{BF}$, et al. Transient uplift after a 17th-century earthquake along the Kuril subduction zone. Science. 2004;306(5703):1918-20.

93. Kleman J, Hättestrand C. Frozen-bed Fennoscandian and Laurentide ice sheets during the Last Glacial Maximum. Nature. 1999;402(6757):63-6.

94. Anderson JB, Shipp SS, Lowe AL, Wellner JS, Mosola AB. The Antarctic Ice Sheet during the Last Glacial Maximum and its subsequent retreat history: a review. Quat Sci Rev. 2002;21(1):49-70.
95. Dyke AS. An outline of North American deglaciation with emphasis on central and northern Canada. Quat Glaciations: Extent Chronol. 2004;2:373-424.

96. Clague JJ, James TS. History and isostatic effects of the last ice sheet in southern British Columbia. Quat Sci Rev. 2002;21(1):71-87.

97. Moreno PI, Denton GH, Moreno H, Lowell TV, Putnam AE, Kaplan MR. Radiocarbon chronology of the last glacial maximum and its termination in northwestern Patagonia. Quat Sci Rev. 2015;122:233-49. 